JOURNAL OF AWARENESS

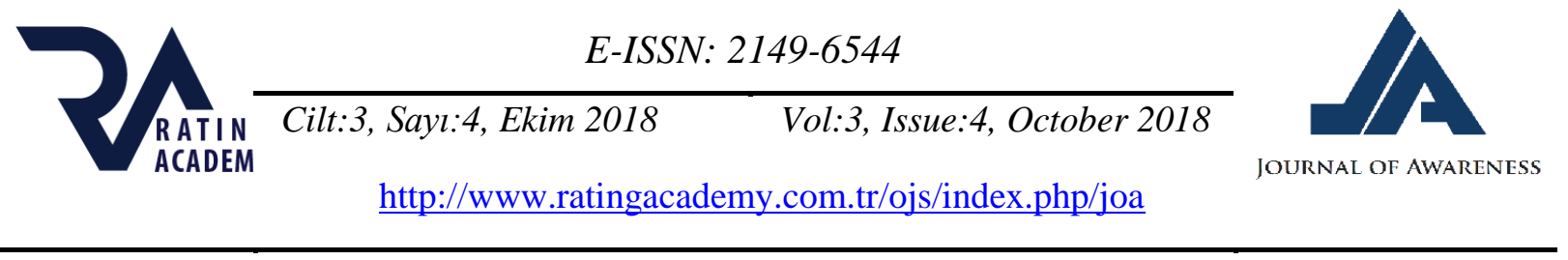

\title{
ETHNO-CULTURAL ANALYSIS OF THE TEXTS OF TURKIC EPIC STORIES
}

Assoc. Prof. Dr. Nurida NOVRUZOVA

Baku State University, Baku/AZERBAIJAN

E-mail:n.nurida@yahoo.com

\begin{tabular}{|c|c|}
\hline ARTICLE INFO & ABSTRA \\
\hline & \multirow{3}{*}{$\begin{array}{l}\text { Each ethnic-national culture is considered the descendant of the nation which he } \\
\text { or she belongs to. Because the attitudes and relationships between personality and } \\
\text { society, culture of speech, the way of thinking are shaped and improved by the } \\
\text { influence of culture and language they belong to. In the ancient Turkish texts, } \\
\text { emotions such as love, praise, inauguration, admonition are expressed by different } \\
\text { means, through elliptical constructions of the language. In the text, these } \\
\text { expressions expressed in the wedding, engagement, naming ceremonies, pre-war } \\
\text { meetings and gatherings, joyful and sad moments in the ethnic groups and tribes, } \\
\text { related to the situation and reasons express the value given to the world and to } \\
\text { life by the Turks. The expression of such emotions took place in all ancient Turkish } \\
\text { texts, including the Book of Dede Korkut, in the form of applauses, praises, naming } \\
\text { rituals. } \\
\text { Our goal is to analyze their meanings of use and compare the roles of expression } \\
\text { such as applause, praise, swearing-in, naming in the attitudes and destiny of the } \\
\text { people. Because the ethno-cultural heritage of characters, as well as the genetic } \\
\text { memory of the culture they carried are expressed and protected in the texts consist } \\
\text { of applauses, praises, naming rituals used in the Book of Dede Korkut. At the same } \\
\text { time, the ideas of the characters about good and evil are well-expressed in this } \\
\text { type of the epic stories. }\end{array}$} \\
\hline & \\
\hline $\begin{array}{c}\boldsymbol{D C} \\
10\end{array}$ & \\
\hline
\end{tabular}

\section{ETHNO-CULTURAL SENSE OF THE TEXT OR NOTION OF "CONCEPT".}

"Cognitive progress" has become one of the determinants of linguistic development in recent years of the twentieth century (Kubryakova, 1994, 34-47). The essence of cognitive linguistics is given in the "brief dictionary in the cognitive linguistics": "Cognitive linguistics is nothing but a triumph of semantics, which is not divided in linguistic and extralinguistic" (Kubryakova, 1996: 41).

The main unit of cognitive linguistics is the concept that is regarded as a lexeme in language. The lexeme and the concept, which have some similarities with each other, also have different features. Thus, the concept has a combination of components (conceptual signs) and semes (semantic signs), while lexeme has semes that combine semantic signs. Therefore, the word with polysemy (multiple meanings) is regarded as a concept with different layers. Consequently, the concept is a semantic formulation that characterizes the linguistic-cultural features and ethno-cultural carriers in this or that form. 
The first thing to notice in the core of the concept is its expressive meaning. This conceptual meaning always lies within inside it. In addition, cognitive layers are preserved in the core of the concept. The text made and the outlooks of the people have a great role in the discovery of these layers.

The concept is closely linked to people's national culture, national character, behavior and mentality of the people, and can therefore be understood as a moving point of any nation that can go in two directions:

I. Learning a conceptual sphere of a nation and identifying its national identity by analyzing the concept of moral culture;

II. The analysis of the internal structure of the concept in the direction of analysis of its new layers. The Anthroponomical concept in the artistic text reflects each of these aspects in its specific form, depending on the group style, in the image of anthroponomy. Concept has national, group and individual forms.

\subsection{The concept of "Love" in the Turkish texts}

In national concepts, psychological forms, such as feelings, wishes, emotions, fears, are selected by different expression images. All the psychological categories are natural for him. Another distinct aspect is that in the context of tense psychological situations, this concept comes in different forms. Here's a great deal of language-rich vocabulary, the ability to Express words with multiple meanings, and possibilities to express semantic depth.

The concept of Love in the Turkish epic texts is the essential and is quite different from the others. In most cases, ordinary words are presented in poetic form, in a different way in the epic stories. As a result, there is an art concept, which is to express what is beyond their scope and boundaries. Of course, these elements belong to the general style of each nation. Sometimes, during the epic text analysis, the concept of the nation is identified as an artistic style stunt with some signs. Now, the capabilities of the text are expanding and paradigms of the different semes of a lexeme can be given within a single text, which is more common in the verbs, but it is possible to use it in other units of the language as well as common names.

Of course, in the epic text, the function of concepts of love and kinship is related to their semantics, which reveals the cultural and historical information of the ethnos and creates a complex of different associations. It creates different imaginations in people's minds, characterized by their national culture, national character, national attitude, moral values and mentality, and therefore, semantically they are difficult to analyze.

There are various tools for expressing concepts as a language unit in the epic text. This episode shows itself in a slightly different way. Thus, in the epic text, the expression forms of the concepts are rich and varied, as it is a collection of general, ethnic taste and national ethics and morality norms. The degree of such conformity depends on the level of imagination of the people who create the epic. Consequently, the concept can be different in the individual epic style.

\section{THE EXPRESSION OF LOVE THROUGH APPLAUSES IN THE TEXTS OF BOOK OF DEDE KORKUT}

The Book of Dede Korkut is entirely a monument of the language, history, traditions and land of the Oghuz Turks. Because epic stories in the Book of Dede Korkut are the artistic mirror for the historical past of "Azerbaijanis, Turkmens and Turks" (V. Jirminski: 519). As it emerged in the Caucasus atmosphere (Bartold: 475, Kononov: 195), it also reflects the national ethical character of the Turks living here. 
The concept of Love is expressed in interesting styles in the rich language and style of "Book of Dede Korkut". Taking into account that the monument of BDK is a textual event realized by the code of epic word of the world model (Rzasoy S. 2004.14), then the clarification of the origin of rituals and concepts in the epic texts will also help to understand the nationalethnic ideas of ancient Turks. The total number of applauses in the "Book of Dede Korkut", which is a monument of Oghuz Turks, is 95. (Encyclopedia of Book of Dede Korkut: 2000, 459). The 10 applauses of these are repeated in different stories: Agh sakalu baban yeri uchmagh olsun! (Let the father's place be paradise!) Haq yandiran chiraghin yana tursin! (Let you be with the light that is burning rightness!) Kadir Tanri seni namerde mohtac eylemesun, xanim! (Let Almighty God never abandon you to the guile of the treacherous, lady!) (BDK; 41).

The form of expression for the comprehension of love is expressed with applauses in the ancient Turkish texts. The applauses represent the polar of powers of goodness and create a wide and rich system of imaginations in the Book of Dede Korkut., (Mammadov, 1999: 176). The applause expressions in the text of the epic are generally expressed in the form of imperative with the word of "olsun" ("let it be"): Yerli siyah taghlarin yikilmasin. (Let your local black arches not fall) Kolgelice kaba aghacin esilmesin. (Let your big shade tree never be cut down), Kanatlarinin ucu kirilmasin. (Let the tip of your wings not break). Chapirken beyaz-boz atin budremesin. (Let your white-grey horse not stumble while riding). Chalishirken qara polat qilincin gorelmesin. (Let your black sword not lose its sharpness while working), Qara olum geldiginde kechit versun. (Let the black death not happen). Saghlighla saghincin, dovletin heqq artirsin. (Let the country increase your rights with the health). Hep akan gorkli suyun kurimasin. (Let your clear running waters never run dry) (BDK; 37-48).

The Oghuz Turks would make applauds to good people, saints and those who do good deeds (Novruzova N. 2015: 241). The applause in the imaginations of Oghuz Turks had its own beliefs and attitudes. According to the beliefs of the Oghuz Turks, prayers are not kept unrealized, they have found their owners. The applause has also psychologically strong influence, for this reason, the Turks escaped from badness, and prayers said was converted into actions that led to the way, which opens to the spiritual rise. (Hajiyev, 1999, 73). Turks, who believed that applause and prayers had a great influence on human nature and future, said in that time that "the applause of gentlemen was applause, the curse of them was a curse" (BDK: 97).

\subsection{Grammar forms of expressions of applauses in the Book of Dede Korkut's texts}

The feeling of love in these epic texts is expressed with the word of "canim" (my dear) and morphological forms "-can (dear),-im,-um,-cighim,-cighim;-ciq, -cik, -cuq,-cuk" (possesive affixes): Dilin uchun oleyin, gelincigum, Qar yuzerine qan dammish kimi qizil yanaklum! (May I die for your tongue, my love! My love with golden cheek like the blood leaking in the snow!) (BDK:93)

The tendency of applauses to the second and third person reveals the modality of wish. The wishes to the second person are imperative: Xanim Qazan, unim anla, sozun dinle! (My Khan Kazan, understand the voice, listen to the word!) (10:68). Kutlu olsun dovletinuz-dedi (Congratulations for your country-he said) (BDK: 63), Qara bashim qurban olsun, oghul sana! Aghiz dilden bir kach kelme xeber mana-dedi (Let my miserable head sacrifice to you, my son! Give me the news to me-he said) (BDK: 39).

\subsubsection{The expressions using with the affixes of predicate "-Sin,-sin,-sun,-sun" (let it be)}

Qanadlarin uclari qirilmasin! (Let the tip of your wings not break), Chaparken aghboz atin budremesun! (Let your white-grey horse not stumble while riding), Chalishanda qara polat 
uz qilincin, gudelmesun! (Let your black steel sword not lose its sharpness while working), Durtusherken ala konderin ufanmasun!! (Let your spare not break while fighting!), Heq yandiran chiraghin yana tursun. (Let you be with the light that is burning right!) Qadir tanri seni namerde mohtac eylemesun, xanim (Let Almighty God never abandon you to the guile of the treacherous, lady!) (BDK:41). This form is still used in modern Azerbaijani language. Halalin haram gormesin; Chiraghin sonmesin; Evinden ev toresin; Elin ellerde qalmasin; Emelin uzune gulsun. (Let your allowed not see forbidden; Let your lamp not switch off; Let your house bring the house; Let your hand not stay in the hands; Let your deed laugh to your face.)

\subsubsection{Applauses arising from with the imperative form "Olsun" (let it be)}

The applauses as the form of expression of love represent the polar of the blessed powers in Dede Korkut. The element "Olsun" (let it be) as imperative form is used in the expression of applauses. The applauses tended to the second person is also used with the word "olsun" (let it be): Agh bircheklu anan yeri uchmagh olsun! Agh saqallu baban yeri uchmagh olsun! (May your white-haired mother's and white-bearded father's place be paradise!)

In modern Azerbaijani and Turkish languages, there are still many applause forms using "olsun" as imperative form: Zehnin iti olsun Elin sayali olsun, İshin avand olsun, İshin ters gelmesin, Yeddi oghlan babasi olasan, Yaxshi gun yarashighin olsun, Suyun gelmish, choreyin bishmish olsun, Tehnen dolu olsun, Haqqin qapisi uzune achik olsun (Let your mind be sharp, your hand be blissful, Let your work be luck, let your work go in its way, let you be the father of seven sons, let the good day be your adornment, Let your water come, your bread bake, your provisions be full, Let the gate of truth open for you!)(12:128).

The applauses and curses as stylistic-expressive means expresses impressively in Dede Korkut. The applauses and prayers in Epos are mythical. Because "the world of belief in the Oghuz is a dream-and-beauty world". The space of Dede Korkut is a communicative space where the wishes of heroes come true" (Rustam Kamal, 2013: 42). The applauses and the curses are also described as the ethno-cultural memory of the characters and the essence of the culture in which they are carriers. So the thoughts of the characters are profoundly understood in terms of good and evil. Prayers of heroes are not just "a matter of faith, but the form of relationships between social status and wish- desire modality". (Kamal 2013, 42) Yerli siyah taghlarin yikilmasin., Golgelice kaba aghacin kesilmesin., Qanadlarinin ucu qirilmasin., Chapirken beyaz-boz atin budremesin., Chalishirken siyah polat qilincin godelmesin. Kara olum geldiginde kechit versun. Saghlighla saghincin, dovletin heq artirsin. Hep akan gorkli suyun kurimasin (Let your local black arches not fall, Let your big shade tree never be cut down, Let the tip of your wings not break, Let your white-grey horse not stumble while riding, Let your black sword not lose its sharpness while working, Let the black death not happen, Let the country increase your rights with the health, Let your clear running waters never run dry) $(B D K: 42)$.

\subsubsection{Expressing of the meaning of applause and praising in the forms of the verb}

Some of the applauses in the texts of Dede Korkut have been used with verbal adjective. Praises with the form of verbal adjective are mostly used.: -an, -en (-yan, -yen), -mish, -mish, mush, -mush, in the few cases, the affix of -dighim created the images of praise expressions. (Ergen Muharrem, 1989:33-36). These forms mean different times as well as the different tones of love of speaker to the lover: Goz achuban gordugum, Konul verib sevdigim, Koch yigidim, shah yigidim, Tatlu damak verib sorushdughum, Bir yasdikta bash koyub imishdigum (My love whom I saw, whom I gave my heart, my courageous, my shah brave, whom I asked with sweet lips, whom I slept with upon the same pillow) (BDK:83). The simile and metaphor are used to praise the lover in these texts. 
Praises and sayings in this epos texts were more commonly used in the contemporary Azerbaijani Turkic, with the most -an, - en (-yan,- yen) affiliation. Qaranqu aksham olanda guni toghan, Qar ile yaghmur yaghanda er kimi turan Qaraghac atlari kishneshtiren, Kizil deve gordugunde kuyruk chirpib kan oylayan!. Avazi kaba kopekleri ghagha salan! Chakmakluca chobanlari dunle yuguren! Kara bashum kurban olsun, kurdum sana! (When the night grows dark, then you come your day. When it rains and snows, then you stand bravely. You make the Karaghac horses utter a neigh. When you see some gold camel, your drive them along with your tail. You fight with the fierce barking dogs; You make run through the night the shepherds who kindle their fires. May my luckless head be a sacrifice to you, my wolf.) (BDK: 45).

\subsection{4. -Chik + expression of applause with the affiliation}

In the Turkish language, the -chik suffix is used for the expression of caressing. Sometimes the suffixes - chik, -cik,-cuk, -cuk are used only or adding possessive case in the first person to these suffixes in Dede Korkut's texts: Dilin ichin oleyim gelincigim! Yoluna qurban olayim, gelincigum! Yalansa bu sozler, gerchek olsun, gelincigum (May I die for your tongue, my love!,May I sacrifice in your way, my love! May my words come true, If I love, my love) (BDK: 66).

\subsubsection{The expression of applause with the repeating of words and phrases}

In the texts of Dede Korkud a saying, repeating itself at the beginning and at the end of the sentence shapes the beauty of the expression and strengthens the meaning. Gozum, gozum ay gozum! Oghul, oghul, ay oghul. Canim paresi oghul! Kara bashim kurban olsun yiğit sana! Aghzin ichin olegim, dilin ichin oleyim. Hey kirk eshim, kirk yoldashim! Kirkiniza kurban olsun benim bashim! (My eye, My eye! My son, my son! Part of my soul! May luckless head sacrifice to you, young!, May I die for your mouth!, May I die for your tongue! My forty wives, forty wives! May my head sacrifice to all of you!) (BDK: 93).

Repeated sayings link the text both grammatically and meaningfully. These repetitions can sometimes be varied and additions are made. The additions are made to these repetitions and they express the peculiarities of the characters. Yalab-yalab yalabiyan ince tonlum! Yer basmuyib yuriyen, Qar yuzerine qan tammish kibi kizil yanaklum! Kosha badam sighmayan tar aghizlum! Kalemchiler chaldighi kara kashlum! Kumrasi kirk tutan kara sachlum! Aslan urighi, sultan kizi! Oldurmeye men seni kiyarmiydim? (My elegant tone, my love with golden cheek like the blood leaking in the snow, walking tenderly! With a mouth too small for two almonds! With brows like a tightened bow! With long black hair that falls to her feet, Heart of Lion, Girl of Sultan! How can I kill you?) (BDK: 93).

\section{FORMS OF APPLICATION WITH APPLAUSE AND PRAISE}

The expression of the feelings of love refers to the value for the world and humanity of those who speak in this language. The concept of love is expressed in the words and phrases said to close people. Like all ancient Turkic texts, the notion of love is used in applying to the people who have close relations, as man-God, mother- son, father-son, husband-wife, brotherbrother, and bravebrave.

The applause and prayers addressed to God are: Urdighin ulamiyan ulu Tanqri! Bastighun belirtmeyn belli Tenqri! Gorurdugun goge yetiren gorklu Tenqri! Qanqdighin qehr eden qahhar Tanqri! Birligine sighindim chelabim, kadir Tenqri! (You are higher than the highest, God!, Who moves with silent footsteps! Glorious God, who send mortal man to heaven, But angered, He destroys the objects of His wrath!, Almighty Allah, I affirm your oneness!) (BDK:96). 
The applause and praise addressed from khatuns (women) to their husbands: Bashim baxti, evim taxti! Xan babamin goygusu, Kadin anamim sevgisi, Ata-anam verdugu, Goz achuban gordugum, Konul verib sevdigim., Begh yigidim Qazan! (The crown of my head, the throne of my house, son-in-law of my father, my love, whom my parents advice, whom I saw while opening my eyes, whom I gave my heart, my brave Kazan!) (BDK: 72).

The applause and praise addressed from the husband to his wife: Beri gelgil, bashim baxti, evim taxti! Evden chixib yugurende serv boylum! Topughunda sarmashanda qara sachlum! Kurulu yaya benzer chatma qashlum! Kosha badam sighmayan dar aghuzlum! Guz almasina benser al yanaqlum. Qavunum, veregim, golegim! (Come here, my love, the crown of my head, and the throne of my house! Walking along so tall, like a cypress tree, With long black hair that falls to her feet, With brows like a tightened bow; With a mouth too small for two almonds; Her red cheeks like the apples of autumn. My melon, my lady, my love!) (BDK:35).

The applause and praise addressed to the brother: Kalmish yigit arkasi! Bize miskin umudu! Bayandin Xanin goygusu! Tulu kushun yavrisi, Turkustanin diregi! Amit soyinin aslani, qaracughin kaplani, Konur atin ayasi, xan Uruzin babasi! Ay Qazan xan, unim anla, sozum dinle (10:63). Veya: Karshi yatan kara taghim yuksegi, qardash! Aqintili gorklu suyimin tashkini, qardash! Guclu belim kuvveti, qarannu gozlerimin aydini, qardash!(BDK:100). (Support of young warriors in time of distress! The hope of the poor! Son-in-law of Bayandin! The young of the full-feathered bird! The main pole of all Turkestan! The lion of Emet Stream! The tiger of Karachuk! Owner of brown horse! Grandfather of Khan Uruz! Understand the voice, listen to the word (10:63)! Or the head of my arch, brother! The flood of my flowing water, brother! My power, the light of my dark eyes, brother!)

The applause and praise in the appealings between mother and son: Ne bileyin, oghul bu qezalar sana haradan geldi? Ol gozunde canin varsa, oghul, xaber mana. Qara bashim kurban olsun, oghul, sana! Aghiz-dilden bir kach kelme xeber mana-dedi (How we know? Why do these accidents happen, son? If your body retains any life, let me know! Let my miserable head sacrifice to you, son! Give me the news!-he said) (BDK: 39).

Sometimes, the love of a son for his mother is related to her status in the family. When expressing his love for the mother, he reminded her labor after his birth: Beru gelgil,aq sutun emdigim! (Come closer, my mother, whose milk I once drank!) (10:87). The most important indicator of parent-child love in Oghuz is loyalty to family honor. Therefore, Uruz agreed with his own death not to let his mother know his enemies: Uruz aydir: Aghzin kurusun ana, Dilin churisin ana! Ana hakki-Tanri hakki denilmeseydi, galgubanu yerimden turaydin, yakanla boghazindan tutaydim...Koy meni qadin ana chengele ursunlar. Koy etimden cheksinler. Anlar bir yediginde sen iki yegil! Seni kafirler bilmesinler, tuymasinlar. Ta kim sasi dinlu kaferin doshegine varmayasan. Saghraghin surmiyesen. Atam Qazan namusini simayasan. Saqin-dedi (Uruz said: May your mouth be dreid up, Mother, May your tongue rot! If the right of mother isn't equal to the right of God, I should at once cut off your lovely head. I should at once spill out your red blood on the earth. Let them kill me. Let them eat my meat! When they eat once, eat twice! Let unbelievers not to suspend! Don't spoil my father's honor! He said silently) (BDK:47).

There is a feeling of great love in the address of the son to the mother, and there is no formalism as his address to his father. The father's love for the son is given by artistic attributes too. The light of my eye, my son, my lion, my hero are mostly used: The words such as light of my eye, my son, my lion are mostly used: Yuca daghim zirvesi, kururu oghul! Karanlik chokmush gozumun ishighi, nuru oghul! Igidim Uruz, aslanim Uruz, Agh sakali babana kiyma oghul! The peak of High Mountain, my son! The light of my dark eye, my son! My brave Uruz, My lion Uruz, Don't be harmful to your white-bearded father! (BDK: 220). 
It is true that the mother's love for the son is more subtle and emotional than the father's love for the son: Dunlugu altin ban evimin ebzesi oghul, Oghul, oghul, ay oghul! Tokuz ay tar karnimda goturdugum oghil! On deyende dunyaya geturdugum oghul! Tolmasi beshikte beledigim oghul! (The backbone of my house with its chimneys of gold, son, my son, son! Son, whom I carried nine months in my narrow womb! Whom I bore in the tenth month and swaddled in the cradle with care!) (BDK:47).

\subsection{Praises related to social relations}

Love of Parent-child based on the perfect morality with the rich history. (In the Dastan, the feeling of love between grown-up and child is expressed in the form of their addressing to each other., Grown-ups usually address the children as "young man": "Where are you coming, young man?" (BDK: 87).

The little ones also appeal to grown up according to their position in their tribe. In these titles, the expression of love is expressed in the aesthetic feelings of the attitude between man (woman) and the woman (man), mother-father toward child, child toward them, the brother toward brother, and the brother toward the sisters.

In Dede Korkut, the attitude of a man towards women is different, but is almost identical to the general context. The man is addressed to his wife not only with love, but also with great respect. Dirsa Khan who has been dishonored by Bayandir Khan because he does not have his children, addresses his wife with affectionate words: Beru gelgil bashim baxti, evim taxti! Evden chixib yugurende serv boylum! Topughunda sarmashanda qara sachlum! Kurulu yaya benzer chatma kashlum! Kosha badam sighmayan tar aghuzlum! Guz almasina benzer al yanaklum! Kavunum, veregim, dolegum! (Come here, my love, the crown of my head, the throne of my house! Walking along so tall, like a cypress tree, With long black hair that falls to her feet, With brows like a tightened bow; With a mouth too small for two almonds; Her red cheeks like the apples of autumn. My melon, my lady, my love!) (BDK: 35).

In the texts of Dede Korkut, the lady's appeal to men is more poetic and emotional. Lover's appeal to each other is expressed in different wayswith emotional expression of love: Vay, al duvaghim iyesi! Vay, alnim-bashim umiri! Vay, shah yigidim, shahbaz yigidim. Toyunca yuzune baqmadighim, hanim yigit! Goz achuban gordigim, gonul ile sevdigim, bir yasdikta bash koydughum! Yolunda oldugum! Kurban oldughum! Vay Qazan begin inaghi! Vay qalin Oghuzun imrencisi Beyrek! (Oh, the owner of my red trousseau! Oh, the promise of my forehead, Oh, my fine young hero! My handsome man! My young khan, whose face I have not yet gazed upon enough! My darling, whom I saw at a glance, Whom I loved with my heart, With whom I shared a pillow, For whose sake $i$ would die and sacrifice my life. Oh, Kazan begh's dear friend! Oh, Khan Beyrek, the symbol of the Oghuz Khanate!) (BDK: 58).

In the story of Deli Domrul, the father of Domrul said: Oghul, oghul ay oghul! Canim parasi oghul! Toghdughunda tokuz bughra oldurdugum aslan oghul! Dunlugi altun ban evimin ghebghesi oghul! Qaza benzer kizimin-gelinimun chichegi oghul! (My son, son, my son! The part of my soul! For whom I once had slaughtered nine camels! Backbone of my house with its chimneys of gold! A flower to my gooselike daughters and brides! ) (BDK: 81). It is clear from this that the son of a boy is important for his family and tribe.

Mothers' love expressions are emotionally and impressively expressed: Gorurmusun ay oghul neler oldu? Canim oghul! Qalkubani yerinden uri turghil! Qirk yigidin boyina alghil! Babani ol qirk namerdden kurtarghil! Yuru, oghil! (Did you se what happened, my son! My life, my son! Stand up and rescue your father from forty treacherous! Go, my son!) (BDK: 40).

The son is considered as the protector of the house, hearth and land in the nation of Oghuz. At the same time he is considered as the guardian of justice and guardianship 
(Jamshidov, 1969, 253). In the Oghuz tribes there were some perfect ethical-moral ties between parents and children that as the children protected the rights of their parents, at the same time, parents protected the rights of their children. (Regardless of whether they were boys or girls). In the Dastan, the love of the brother toward brother (in the cases of Kazan and his brothers, Sedrak and Egrek) is given more clearly. Sedrak did not go to the gerdek of bride (a special place chosen for the bride in the boy's house at the wedding) till he rescued Egrek, his elder brother from captivity. Mere qavat kizi, agham bashina yemin etmishim, donmegim yok- dedi. (He said that I swear to the head of my owner, I will not return). The loyalty to swearing is the main features of Oghuz heroes. To break promise is equal to the death in Oghuzs. In the meeting of Sedrak with Egrek, their brotherly love is expressed emotionally and effectively: Aghzin uchun oleyim qardesh! Dilin uchun oleyim qardesh! Ermi oldin, yigitmi oldin qardesh! Qaribligha qardashin isteyu senmi geldin qardash? (I could die for your mouth, my brother! I could die for your tongue, my brother! Have you grown into manhood already, my brother? Did you ride so far just to search for your brother, my brother?) (BDK: 115).

\section{THE TRADITION OF "NAMING" IN TURKS AND ITS NATIONAL AND ETHNIC MEANING}

In Epos, as well as in Dede Gorgud, it is interesting to see the rituals reflecting the national- ethnical traditions of the Turks, their historical-ethical character, mythological thinking. One of such ancient and important rituals associated with the lifestyle, tradition and Outlook of the ancient Turks is naming (giving name). Naming is one of the most ancient and important traditions of the Turkic peoples. Because a name is the most important fact that confirms the creature and existence of man. In mythical thinking of the Turks, the name is a symbol of creation; it has already been created before the man. According to the ancient mythical thought of the Turks, the sacred names were covertly called or other names were called because they were forbidden to sound. Creation of the universe according to mythology of Altai Turks, which connects the creation of the world, is also related to the naming. According to Oghuzname, the world emerged with the word "Bolsun ki!" (let it be). The tradition of the meaning and selection of names in the national idea of Turkish peoples is due to their mythical thinking. The names allow the Turks to learn about the politics of the Turks, sources of mythical thinking, their initial beliefs, their primitive views.

A similar mythical meeting is also given in the naming ritual given in the Book of Dede Korkut. The performer of the naming ritual is Dede Korkut. According to the Dede Korkut story of famous Azerbaijan thinker and playwright M.F. Akhundov, Dede Korkut gave the name not only to the heroes of Oghuz, but also everything-objects, plants, events and made a mistake when he called the four things: Geline ayran demedim men Dede Khorkhud. Ayrana doyran demedim men Dede Khorkhud. Iyneye tiken demedim men Dede Khorkhud. Tikene soken demedim men Dede Khorkhud. (I didn't call the bride as ayran (sour milk), me, Dede Khorkhud, I didn't call the ayran as saturated, me, Dede Korkut, I didn't call the needle as sewing (sour milk), me, Dede Korkut, I didn't call the sewing as disassembling, me, Dede Korkut.), (Hadjiyev: 2002,14).

It is interesting that in this example, the name of Dede Korkut is given as Khorkhut. According to T. Hadjiev, this was due to the fact that the author could have received this text from Evliya Chelebi, the Turkish traveler of XVII century or from the Central Asian folklore (Kazakh). (Hadjiev, 2002:14).

\subsection{Description of the naming ritual in the Book of Dede Korkut}

The naming is not a simple ritual in the Turks, but it means the origin, the first, the beginning of everything and in the book of Dede Korkut, this mission falls on Dede Korkut, Korkut Ata. The book's naming ritual is different from the ancient mythical thought. So, in the 
ancient Turkish mythical thinking, the names create before the things, people, that is, the name is more initial. In the book, the naming of braves is more of a public meaning. It does not give birth to children when it comes to the traditions of Oghuz Turks. Upon reaching the age of maturity, the name is based on his braveness shown. The name is not given away to the braves, , simply not given. When they reach the age of maturity, they gain themselves by their intelligence, strength and personal qualities. Because it is life, respect, high moral guarantee in the Oghuzs.

Oghuz braves earn their names for their deeds when they reach the age of 15-16 - at the age of youth. "Ol zemanda bir oghlan bash kesmese, kan dokmese, ad komazlardi.! (If the man cannot cut the head, shed the blood, he will not gain the name!) (BDK; 53). Not gaining the name was a great misfortune while reaching the age of fifteen or sixteen. Because getting a name is a right for independent life. In the story of Bamsi Beyrek when Baybore heard the braveness of his son Bamsi he said:" Mere, benim oghlim bashmi kesdi, qanmi dokdi?" Beli, bash kesdi, qan dokdi, adam axtardi!"-dediler. "Mere, bu oghlana ad koyasinca varmidir?"dedi." Beli, sultanim, artiqdir!" -dediler. (Did my son cut the head, shed the blood? Yes, he did-they said. Did he gain the name?- he said. He had already gained- they said.) (BDK; 54) Hence, the public opinion defines the naming of the brave.

A ceremony-ritual is held in the honor of the brave who is given the name in the Oghuz Turks and a good horse for riding, a crown, a wealth of gifts are given to him. "Dedem Qorqut geldi, oghiana ad kodi. Aydir: Sozum dinle, Baybore beg! Allah-teala sana bir oghul vermish, tuta versun! Aghir sancaq goturende muselmanlar arxasi olsun,! Qarshu yatan qara qarli taghlardan ashar olsa, allah-teala senin oghlina ashut versun. Sen oghlini "Bamsi" deyu oxsharsan.; bunin adi Boz ayghirliq Bamsi Beyrek olsun! Adini ben dedim, yashini allah versun"- dedi. Qalin Oghuz begleri el goturdiler, dua qildilar" Bu ad bu yigite qutlu olsun!" dediler. (Dede Korkut came and gave the name to the boy and said: Listen to me, Baybore! Allah gave you the son and made him beneficial! Let all Muslims support him! Let Allah help your son! You caressed your son as "Bamsi". Let his name be Bamsi Beyrek of the grey house! I gave his name, and may Allah give him the years of life! The gentlemen of Oghuz raised their hands, prayed and congratulated.) (BDK; 54).

In the story of "Boghach Khan, Son of Dirse Khan" of the book, Boghach also shows the braveness, deserves to be named. Dede Korkut comes, names the brave and praises him: "Chaghirdilar. Dedem Qorqut gelir oldi. Oghlani alib babasina vardi. Dedem Qorqut oghlanin babasina soylamish, gorelim ne soylamish: Hey Dirse Xan! Oghana beglik vergil, Taxt vergil, - erdemlidir! Boyni uzin bedavi at vergil, Biner olsun, hunerlidur! Agh ayildan tumen koyun vergil, Bu oghlana shishlik olsun, erdemlidir! Qaytabandan qizil deve vergil bu oghiana, Yuklet olsun, hunerlidir! Altun bashlu ban ev vergil bu oghlana, olget olsun, erdemlidir! Chikin qushlu cubbe ton vergil bu oghlana, Geyer olsun, hunerlidir! (When they called for Dede Korkut, he came. He took the young man to his father and said to him: O Dirse Khan! Give this young man a principality now! Give him a throne for the sake of his virtue! Give him also a Bedouin horse, he can ride - such a capable man. Give him ten thousand sheep to make shish kebab for himself, he has virtue. Give him next a red camel from out of your herd. Let it carry his goods, he has virtue. Give a large lavish tent with a golden pole to provide him with shade. Give a suit to this man and a coat that has birds on its shoulders. Let him wear both of these, he has a skill.) (BDK; 36).

In this text, exclamation and address (hey Dirse Khan), imperative form of the verb "gil" (vergil ), "ol” (be) ("binar olsun", "shishlik olsun", "yuklet olsun”, "kolge olsun", "geyer olsun" (let it be thousand, let it be shish kebab, let it be carried, let it be shade, let it be for wearing) give the text emotionality and uplift. These expressions create a special beauty in the 
epic texts. In the texts of the Book of Dede Korkut, the national characteristic of the text is expressed more clearly in the form of appeal. The text expresses the love of the social environment and the community to the brave.

\section{NATIONAL AND ETHNIC MEANINGS OF THE CONCEPT "SWEARING- IN" (INAUGURATION) IN THE TURKISH TEXTS}

Swearing-in is a ceremony held to strengthen the word, "fulfilled with confirmation of the truthfulness of what is said and promise by witnessing of a holy being". Swearing-in is widely spread in all nations, and it is expressed differently in different languages and cultures. In the culture of the Turks, including the Azerbaijanis, it existed in the political, legal and social life from ancient times and was widely used today at the individual level.

In general, it is said that the words related to swearing-in are related to the beliefs. Along with Buddhism, shamanism, all monotheistic religions-in Judaism, Christianity, and Islam-also contain words, phrases, and different customs related to swearing-in.

The roots of the swearing by sacred being dates back to the Sumerians, even to the ancient Egyptians. It is known from the ancient times that the Turks swore by swords and weapons. There is more people that associate the worshipping of Turks to the sword with Buddhism. Actually, the worship to any subject is related to the belief of Buddhism. However, historic sources say that Germans, Ancient Greeks, Scythians have traditions such as worshipping to the swords and other weapons.

Especially in the medieval era, taking the swords and swearing of kings and knights are also included in the literary texts and historical films (film of The First Knight).

In the swearing-in texts contained, Ahdnames ("the Bill of Oath") and ancient Turkic texts contain more information about Turks' swearing to the sword. A Turkish monument of the Middle Ages, Diwan Lughat al-Turk ("Compendium of the languages of the Turks") of Mahmud al-Kashgari, has information about swearing of Turks to sword, and considering the sword sacred. The author clarifies the meaning of the verse "Goy girsin, kizil chiksin" ("let the earth and sky be my witness"): "This word has another meaning. When a few tribes such as Kyrgyzs, Kazakhs, Yabakus, Kipchaks got out of the sword setting in front of them and said: "bu goy girsin, kizil shixsin" ("let the earth and sky be my witness"). It means that if I break my promise (if I lie), let the sword be in my blood, and let it take revenge on me. Because they worshipped to the sword" (Inan Abdulkadir, 281).

In the Dede Korkut text, the tradition of swearing by the weapon of the Oghuz Turks, especially the sword, took place in the story called "Bamsi Beyrek of the Grey Horse". Beyrek said while swearing: "kilincima toghranayin, oxuma sancilayim, yer kibi kertleyin, toprak kibi savrilayin" saghlikla varcak olursam, oghuza gelub seni helalligha almaz isem"-dedi ("Let me be pared by my sword, let me perforated by my arrow, let me turn the land, if I don't you get with absolution when I came to Oghuz" - he said) (BDK; 59).

As swearing-in is a sacred obligation, it is also important for those who violate it to be punished. However, the usual habit of forgiving the violator is included in Turkish texts, including Dede Korkut. Beyrek forgave the liar, who brings the story of fake death, wants to Beyrek's fiancee, on condition that he passed under the sword of Beyrek. In ancient Turks, the sword was considered sacred, and the passage under it was considered to be sufficient for the forgiving of sins.

Inan Abdulkadir, who writes the use of the word "and (swearing)" in different ways, emphasizes the use of the same word in all Turkic-speaking tribes and clans. This word, which is used in most of the Turkic languages as and, ant (swearing) and it is used as "andigar" by 
Shamanist Turks-Yakuts "andigar" and "antah" by Jewish Turks and Chuvashs. Turks use this word as "emin etme" (an assurance). (Inan Abdulkadir, 1998: 279).

It is said that the words of swearing-in are related to the beliefs. There are traditions related to swearing in all of the monotheistic religions, Jewish, Christian, and Islamic, along with Buddhism. In the Islamic community and the figh there is a great importance for assurance. The assurance is divided into two categories: those which are done in the name of Allah and those which are done in the name of the other but Allah. The assurance done in the name of Allah is classified among themselves too. (Zakir Avshar: 16.)

\subsection{The traditions of the ancient Turks related to swearing}

There are various sources of information related to swearing of ancient Turks. Inan who said that the first knowledge about it dates back to the 1st century B.C. noted the "Andname" (swearing) concluded between Khagan of Hun, Huhunia (Xuhunya) and Chinese ambassadors Chan and Min for the friendship and brotherhood. The text of this and (swearing) was as follows: Xan ve Hunlar bir sulale teshkil edirler; nesiller boyunca birbirlerini aldatmazlar, birbirlerine hucum etmezler. Oghurluq haqqinda birbirlerini xeberdar ederler. Oghrulari cezalandirarlar, zererleri odeyerler, iki terefden birine dushmen hucum ederse, esgerleri ile komek ederler. Bu andi kim pozsa, tanrinin qezebine gelsin. Nesiller boyunca bu andin cezasi altinda inlesin (Khans and Huns are considered as one tribe; they never lie to each other; they never attacked each other. They always warned each other about robbery. They punished the robbers, paid the loss, helped each other with the army during the attack of enemies. If any man break this oath, let God be angry with him. Let him suffer from punishment for eternity) (Inan Abdulkerim. 1998, 279). The sentence of this sentence was appreciated till the Chinese ambassadors returned to the palace, and ritual sacrifices were required to get rid of its responsibility. An interesting matter is the ceremonies related to ritual sacrifices in order not to be punished while breaking the oath.

Likewise, there are information about the agreement signed between the Uyghur Turks and the head of Chinese army while talking about VIII century in the Chinese sources: Chinli ordu bashchisi bele dedi: Tan sulalesinden Goy oghluna on min il, Uyghur Xaqanina da on min il. Her iki Hokmdar sulh ichinde olsunlar, hansi bu anlashmani pozarsa, doyushde cani chixsin, nesilleri yox olsun." And sherabi getirilerken Uyghur Bashbughlari" Senin andina and edirik" dediler. The head of the Chinese army said: "Ten thousand years to the son of Goy from the dynasty of Tan, ten thousand years to Uighur Khagan too, May both of the rulers are in peace, if any of them breaks this agreement, may they be in the war, my they generation destroy". In addition, when the wine of oath was brought, the Uighur Bashbughlari said, "We swear too". (Inan Ebdulkarim, 1998: 280).

According to the Byzantine historian Menander lived in the sixth century, there was such text of swearing referring to the Avar Khagan, Bayan: Sava uzerinde korpu qurmaqla romalilara zerer vermek niyyetinde isem, men Bayan Xan mehv olum, butun avarlar mehv olsun; goy ustumuze uchsun, Goy tanrinin alovlu oxlari bizi oldursun, daghlar ve mesheler uzerimize yixilsin; Sava sulari dasharaq bizleri yutsun-boghsun". ("If I'm going to hurt the Romans by building a bridge over the Sava, let me destroy, may all the avars destroy; let the heavens overtake us, and may the flaming arrows of the heavens shall slay us, and the mountains and the woods shall fall upon us; The waters of Sava are overflowing towards us.") (Inan Ebdulkarim,1998:280).

As it seems, swearing-in ceremonies indicates the obligations and responsibility of the violator. Also, there are curses for violators. (hansi bu anlashmani pozarsa, doyushde cani chixsin, nesilleri yox olsun; goy ustumuze uchsun, Goy tanrinin alovlu oxlari bizi oldursun, daghlar ve mesheler uzerimize yixilsin; Sava sulari dasharaq bizleri yutsun-boghsun - If any 
man break this agreement, let him die in the fighting, let his generations disappear; let the heavens overtake us, and may the flaming arrows of the heavens shall slay us, and the mountains and the woods shall fall upon us; The waters of Sava are overflowing towards us.). These curses are meant to prevent the parties from violating their obligations.

The perception of swearing is very important in the culture and life of the Turks. And when they swore, they swore to God, the most sacred existence for them, and to the things they worshiped. In ancient traditions of the Turks, there are much swearing connected with the war, obligations taken during the peace process and the description of the ceremonies related to it. Some information about the beliefs and the ceremonies of the Turks is protected in the ancient sources of China, Rome and others. Sedrak didn't go to the gerdek of bride (a special place chosen for the bride in the boy's house at the wedding) till he rescued Egrek, his elder brother from captivity in the Book of Dede Korkut. Mere qavat qizi, agham bashina yemin etmishim, donmegim yok-dedi. The loyalty to swearing is the main feautures of Oghuz heros. To break promise is equal to the death in Oghuzs. In the meeting of Sedrak with Egrek, their brotherly love is expressed emotionally and effectively: Aghzin uchun oleyim kardesh! Dilin uchun oleyim kardesh! Ermi oldin, yigitmi oldin kardesh! Qaribligha kardeshin isteyu senmi geldin kardesh? I could die for your mouth, my brother! I could die for your tongue, my brother! Have you grown into manhood already, my brother? Did you ride so far just to search for your brother, my brother?) (BDK: 115).

\section{CONCLUSION}

Thus, ethno-cultural analysis of Turkish texts helps us to learn the historical ethnographic view of our people, their nationalistic traditions and their mythological outlook. Applauses, texts of swearing, rituals of naming express ethnic and cultural memory of characters and culture which is their genetic carrier. Applause texts usually hold more judgment. Therefore, the applause expressed in imperative forms is stronger, more brilliant. The applauses in texts is in the form of idioms, expressed in the meaning of wish and expressed in different images of modality. The applauses in Epos are told by Dede Korkut. There are six applause text at the beginning of the dastan. Heq size yaman geyurmesun Dovletiniz payende olsun, xanim hey! El-evunuzde chalib-ayidan ozan olsun! Azib gelen ghezayi tenqri savsin, hanim hey! (Let always be rightness! May your country be stable, lady! Let the ozan play aand dance in your house! Let God save us!) (BDK: 41). There are 14 applauses in the story of "Boghach Khan, Son of Dirse Khan", and in the story of "How Salur Kazan's House was Pillaged" There is the applause of Salur Kazan's looting. 9 of them are repetitive, but 5 applauses are added: Ahir-soni ari imandan ayirmasun! Amin deyenler didar gorsin! Agh alninda besh kelme dua kildik kabul olsun! Allah veren umudun uzulmesin! Yighishtirsin turushdursun gunahlarini gorklu Muhammed Mustafa yuzi suyina baghishlasin hanim hey! (May you not part with faith! May those saying "Amen, amen" come to see the face of Allah. May you be always hopefully! May He save you from your sins and forgive them for the sake of Mohammed Mustafa, O my khan!) (BDK: 51). These applauses are repeated in all stories. Dede Korkut, an elder of the tribe, awards those who deserve applause with applause, those who deserve cursing with curse. In the applause, the meaning is directed to a person and is an individual, expressing the attitude of the person to the addressed person.

And the belief that the sayings of swearing created connected to belief is stronger among others. The colorful forms of the sayings of swearing prove that the culture of the Turks was open to other cultures, and different beliefs, views and customs had been lived and preserved in parallel for a long time.

The naming in the Turks is a public and social issue. The name-giving to the braves in Epos texts have mostly social meaning. It turns out that the name is not given to the children 
when they were born according to the traditions of the Oghuz Turks. . Upon reaching the age of maturity, the name is based on his braveness shown. The name is not given away to the braves, when they reach the age of maturity; they gain themselves by their intelligence, strength and personal qualities. 


\section{REFERENCES}

Abdulla Kamal (2009),From the myth to the writing or epic among the mysteries. Part I, Baku.

Demirchizade A.(1959); ( 1999), The language of the epic stories of Book of Dede Korkut, Baku.

16.Haciyev. T.(2002), About the identity of Dede Korkut again, Dede Korkut Magazine, 2002 // II.Baku.

Novruzova N.S.(2015) Basic approaches to the study of the text: Theories. considerations. problems. Baku, $258 \mathrm{p}$.

Inan Abdulkadir (1998) Swearing in the ancient Turks and Folklore; AU; DTCF Review, Vol. VI, Issue 4, Ankara, p. 279.

Bartold V.V. (1962), The book of my Dede Korut. M-L. Ergen Muharrem( 1963), The book of Dede Korkut. II İndex -Grammer. Ankara.

Aliyev Yadigar. “"Book of Dede Korkut and phonological structure of artistic text, Baku, 2006.

Aliyev Yadigar . "Book of Dede Korkut and structural-semantic organizing of artistic text. Baku, 2005

Alizade S. (1999), Manuscripts of Vatican and Dresden of the Book of Dede Korkut//

Book of Dede Korkut-1300. News of Baku State University, Series of Humanitarian Sciences, Bakiu

Alizade S.(2001), Linguistic-textual features of Turkmen edition of "Dede Korkut", Scientificliterary collection of "Dede Korkut", 1, Baki, 2001;

Bartold V.V. (1968), the Turkic Epic of the Caucasus. Compositions, Moscow.

Dede Korkut Encyclopedia (2000). I, Vol. II. Baku.

Ergen Muharrem. (1989), The book of Dede Korkut. V. I Ankara.

Haciyev T.(1999), Dede Korkut: our language, our thought. Baku.

Jirminsky V.Sh. (1974) Turkic heroic epos, Moscow.

Kononov A.N. (1958), Foreground Turkmen, M-L., 1958.

Kubryakova E.S. Demiankov V.Z., Pankrats U.G., Lusina L.G. (1996) .The brief dictionary of cognitive terminology / Under general ed. E.S .Kubryakova. -M.

Kubryakova E.S. (1994) The initial stage of the formation of cognitiveism: linguistics psychology - cognitive science // Questions of linguistics. a. - № 4 - p. 34-47.

Rzasoy Seyfaddin.(2004) Paradigms of Oghuz myth, Baku.

Zakir Avshar "Biat dan Yemine” ( Turkiyyat journal ,2012, issue-10. p. 16.) 